\title{
THE COMPARISON AND CHARACTERISATION OF GLYCOLYTIC MYCOPLASMAS ISOLATED FROM THE RESPIRATORY TRACT OF SHEEP
}

\author{
G. E. Jones, A. Foggie, D. L. Mould and Sally LivitT \\ Moredun Institute, 408 Gilmerton Road, Edinburgh, EH17 7JH
}

\section{Plates III AND IV}

THE original isolations of glycolytic mycoplasmas in Scotland were made by Mackay, Nisbet and Foggie (1963) from cases of sheep pulmonary adenomatosis (SPA). Identical (" Type A ") mycoplasmas were later isolated from pneumonic but not from normal lungs of sheep, and from the upper respiratory tract of apparently healthy sheep (Mackay, cited by Cottew and Leach, 1969). Krauss and Wandera (1970) compared mycoplasmas recovered from cases of SPA in Kenya with other mycoplasmas, including the Scottish MS strain originally isolated by Mackay from a case of SPA. The Scottish strain was placed in one of three serogroups.

Mycoplasmas recovered from lambs and sheep in Queensland, Australia, by St George et al. (1971) have been characterised by Carmichael et al. (1972), and the name Mycoplasma ovipneumoniae proposed. Glycolytic mycoplasmas isolated from the respiratory tract of sheep in Victoria, Australia (Cottew, 1971; Furlong and Cottew, 1973), and in New Zealand (Clarke, Brown and Alley, 1974) were identical to the Queensland strains of M. ovipneumoniae.

The purpose of this investigation was to compare the biochemical and serological reactions of glycolytic mycoplasmas isolated from SPA cases, pneumonic sheep and apparently healthy sheep in Scotland with a Queensland strain of $M$. ovipneumoniae.

\section{MATERIALS AND METHODS}

Strains examined. These are listed in table I. All strains isolated in this laboratory were cloned at least four times by serial transfer of single colonies from agar plates to broth. The possibility that the strains were L-forms was eliminated by five consecutive subcultures on solid medium (OA) from which bacterial inhibitors had been omitted. No reversion to bacterial forms occurred.

Isolation media. Broth medium (OB) comprised (v/v) 20\% of Brain-Heart Infusion (Oxoid Ltd., London), $60 \%$ of Medium 199 (Burroughs Wellcome, Beckenham, Kent), $10 \%$ of inactivated swine serum and $10 \%$ of fresh yeast extract (Marmion, 1967), supplemented with ampicillin, $1 \mathrm{mg}$ per ml (" Penbritin ", Beecham Veterinary Products, Crawley, Sussex) thallium acetate $0.025 \%(\mathrm{w} / \mathrm{v})$ and phenol red $0.006 \%(\mathrm{w} / \mathrm{v})$. The medium was adjusted to $p \mathrm{H} 7 \cdot 6-7 \cdot 8$ with $\mathrm{M} \mathrm{NaOH}$. Solid medium (OA) differed in containing $15 \%(\mathrm{v} / \mathrm{v})$ of

Received 25 Mar. 1975; accepted 18 June 1975.

J. MED. MICROBIOL. - vol. 9 (1976) 
TABLE I

Strains of ovine glycolytic mycoplasmas examined

\begin{tabular}{|c|c|c|}
\hline \multirow{2}{*}{$\begin{array}{l}\text { Strain } \\
\text { number }\end{array}$} & \multicolumn{2}{|r|}{ Origin of strains } \\
\hline & Material & Animal \\
\hline $7 Z 97$ & Lung & Naturally-occurring case of SPA \\
\hline $8 \mathrm{Z} 56$ & Lung & Naturally-occurring case of SPA \\
\hline 611 & Lung & Naturally-occurring case of SPA \\
\hline 652 & Lung & Naturally-occurring case of SPA $\dagger$ \\
\hline 658 & Lung & $\begin{array}{l}\text { Experimental SPA case produced by the } \\
\text { intra-tracheal inoculation of SPA lung }\end{array}$ \\
\hline $\begin{array}{l}650 / 21 \\
672 / 9\end{array}$ & $\begin{array}{l}\text { Nasal swab } \\
\text { Nasal swab }\end{array}$ & $\begin{array}{l}\text { Apparently healthy 6-month-old lamb } \\
\text { One of a flock of housed adult sheep } \\
\text { showing pneumonic symptoms }\end{array}$ \\
\hline $956 / 2$ & Nasal swab & $\begin{array}{l}\text { One of a fiock of ewes at grass showing } \\
\text { pneumonic symptoms }\end{array}$ \\
\hline $\begin{array}{l}697 \\
\text { Y98* }\end{array}$ & $\begin{array}{l}\text { Lung } \\
?\end{array}$ & $\begin{array}{l}\text { Housed lamb with pneumonia } \\
\text { Sheep }\end{array}$ \\
\hline
\end{tabular}

* The Queensland strain of Mycoplasma ovipneumoniae obtained from Dr T. D. St George.

+ Isolated initially in primary sheep-lung cultures.

SPA $=$ Sheep pulmonary adenomatosis.

inactivated swine serum, $55 \%$ (v/v) of Medium 199, and Agarose (B.D.H., Poole, Dorset) $0.75 \%(\mathrm{w} / \mathrm{v})$. The Agarose was autoclaved with the Brain-Heart Infusion and the other constituents were added when the suspension had cooled to $56^{\circ} \mathrm{C}$.

Biochemical test media. The basic media, EA and EB, were based on OA and OB respectively, but with Eagle's Minimal Essential Medium (MEM) substituted for Medium 199 and phenol red omitted unless specifically required. All strains were subcultured twice in EB before being tested. Paired broth cultures were incubated aerobically and, by being overlaid with sterile paraffin, anaerobically. Paired agar plates were incubated, one in a candle-jar and the other in an atmosphere of $95 \% \mathrm{~N}_{2}$ and $5 \% \mathrm{CO}_{2}$, as described by Aluotto et al. (1970). For all biochemical tests, controls included test media inoculated with sterile broth or agar blocks.

Rabbit broth (RB). For the production of hyperimmune serum in rabbits strains were grown in RB, which was based on $\mathrm{OB}$ but with rabbit infusion broth (Taylor-Robinson et al., 1963) and inactivated rabbit serum substituted for brain-heart infusion and swine serum respectively.

All cultures were incubated at $37^{\circ} \mathrm{C}$. Routine broth cultures were incubated aerobically and cultures on solid medium in a candle-jar.

Biochemical tests. The oxidation-fermentation, phosphatase production, optochin sensitivity and tetrazolium, tellurite and methylene-blue reduction tests were performed according to the methods of Aluotto et al. (1970) but with EA or EB as the basic medium. In addition, the complete methods and media of Aluotto et al. (1970) were used for the hydrolysis of gelatin and for the casein and serum digestion tests.

The inhibitory effect of $0.02 \%$ methylene blue on $24-\mathrm{h}$ broth cultures was investigated by the method of Kraybill and Crawford (1964) but employing EB as the culture medium. The test for the hydrolysis of aesculin was performed by the method of Williams and Wittler (1971), with EA as the basic medium.

The determination of specific substrate requirement was performed as follows. The medium used (TSM) comprised (v/v) $60 \%$ of MEM, $18 \%$ of Hanks' balanced salt solution (BSS), $10 \%$ of Brain-Heart Infusion, $1 \%$ of Serum Fraction (Difco Laboratories, West 


\section{GLYCOLYTIC MYCOPLASMAS FROM SHEEP}

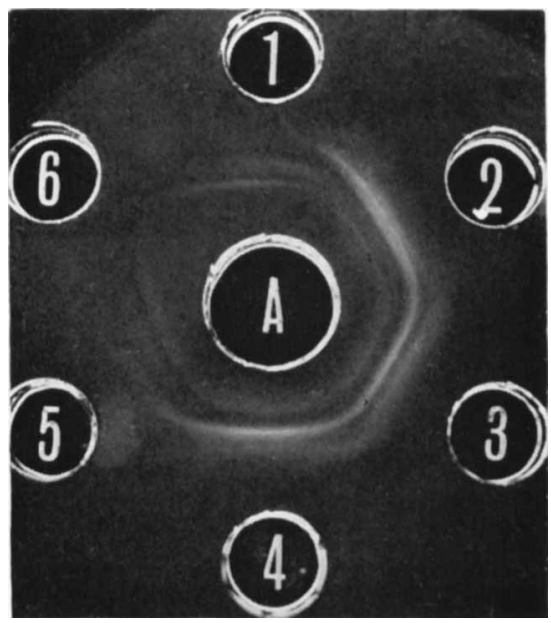

FIG. 1.-Agar-gel double diffusion with antiserum to strain 658 in the centre well (A), concentrated mycoplasma suspensions in wells $1-5(1=$ no. $956 / 2,2=$ no. $611,3=$ no. $658,4=$ no. 697 , $5=$ no. Y98), and normal rabbit serum in well 6. 
GLYCOLYTIC MYCOPLASMAS FROM SHEEP

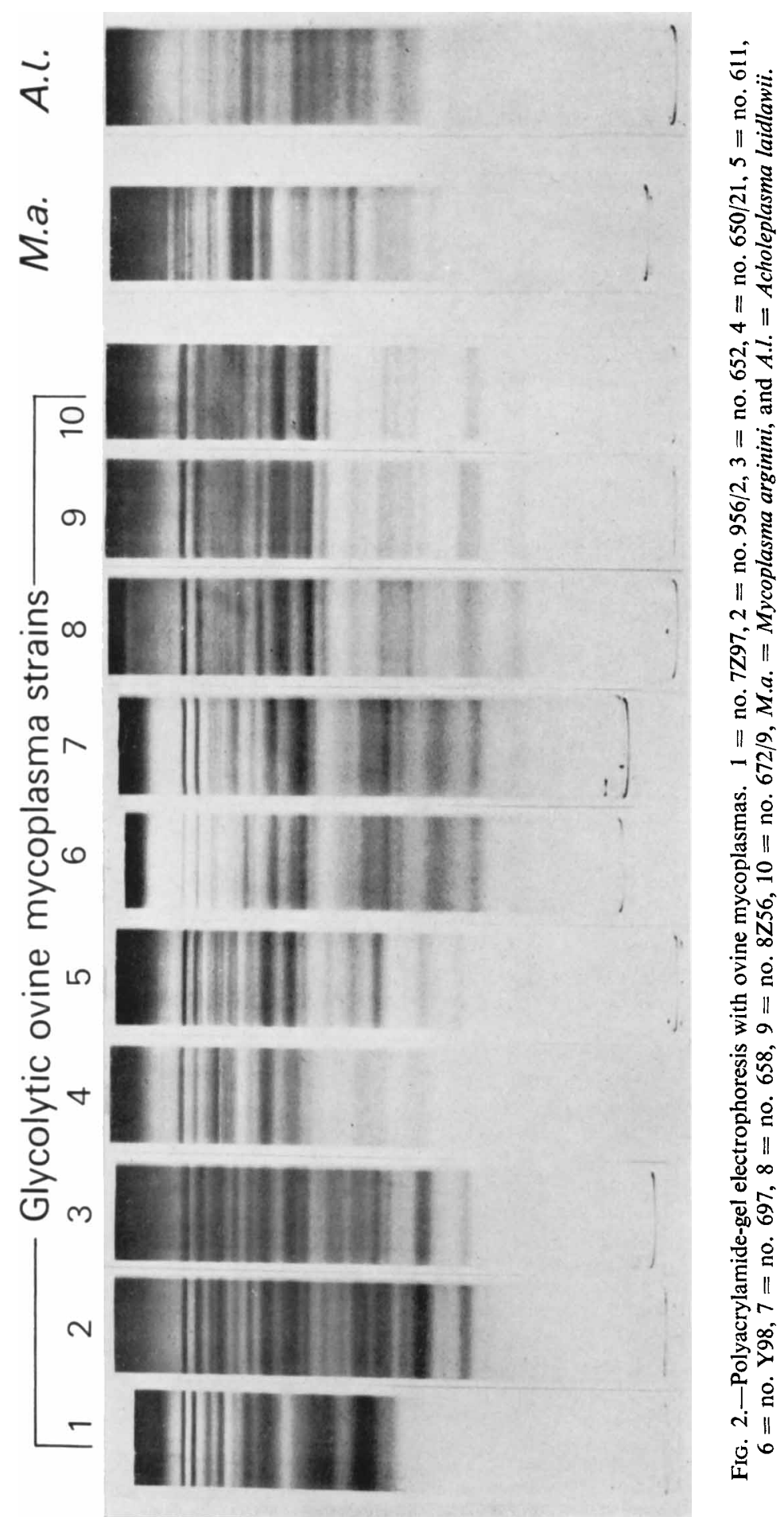


Molesey, Surrey), $1 \%$ of fresh yeast extract and $10 \%$ of test substrate solution, and was supplemented with ampicillin, thallium acetate and phenol red at the same concentrations as in OB. The BSS was prepared without glucose. Before the addition of the test substrates, the medium was exhaustively dialysed against several changes of BSS, filtered through Millipore filters of $0 \cdot 22-\mu \mathrm{m}$ average pore diameter and adjusted to $p \mathrm{H} 7 \cdot 2$. The test substrates contained $10 \%(\mathrm{w} / \mathrm{v})$ of either glucose, arginine or urea in distilled water, the control substrate being BSS. Suspensions of organisms were prepared according to the method of Edward (1971), the washing and suspending medium (PM) being BSS with $1 \%(\mathrm{v} / \mathrm{v})$ of Serum Fraction and the same concentrations of antibacterial supplements as in OB. The test method consisted of pipetting $0.2 \mathrm{ml}$ of the organism suspension or sterile PM into $1.8 \mathrm{ml}$ of test and control TSM, and measuring the $p \mathrm{H}$ of the broth after aerobic incubation for 1-2 days.

Ability to form "films and spots" was examined on (a) EA containing $10 \%(\mathrm{v} / \mathrm{v})$ of concentrated egg yolk emulsion (Difco Laboratories) and $5 \%(\mathrm{v} / \mathrm{v})$ of inactivated swine serum (Fabricant and Freundt, 1967), and (b) EA incorporating (v/v) $20 \%$ of inactivated swine serum and $50 \%$ of MEM.

Hydrogen peroxide production was detected by the methods of Lind (1970) and Cole, Ward and Martin (1968), with EA as the basic medium.

Haemolysis. Haemolysis of erythrocytes was examined by the method of Somerson, Taylor-Robinson and Chanock (1963). Guinea-pig, horse, sheep and human group O erythrocytes were used. The results were read 24 and $48 \mathrm{~h}$ after overlayering the agarerythrocyte suspension on to the mycoplasma colonies and were classified according to the system of Aluotto et al. (1970).

Sensitivity to antibacterial substances. Sensitivities of the strains to digitonin (Sigma Chemical Co.) $1.5 \%(\mathrm{w} / \mathrm{v})$, sodium polyanethol sulphonate (SPS) (Sigma Chemical Co.) $5 \%$ and $20 \%(\mathrm{w} / \mathrm{v})$, optochin, (Oxoid Ltd) $0.025 \%(\mathrm{w} / \mathrm{v})$ and 11 antibiotics were determined with impregnated disks by the flooded-plate technique. All antibiotic disks were obtained from Mast Laboratories Ltd, Liverpool, except those containing tylosin (Elanco Products Ltd, London). Filter-paper disks impregnated with digitonin and SPS were prepared by the method of Freundt et al. $(1973 a)$. Undiluted 24-h broth cultures were flooded on to dried OA plates $85 \mathrm{~mm}$ in diameter, the excess fluid was removed and the plates were dried for $15 \mathrm{~min}$. before peripheral placement of the disks. The plates were incubated aerobically, and the results read 4-6 days later.

Filtration studies. Filtration experiments were performed on 24-h broth cultures by means of Millipore filters of $0.80 \mu \mathrm{m}, 0.45 \mu \mathrm{m}$ and $0.22 \mu \mathrm{m}$ average pore diameter. Titrations of the number of organisms were performed before and after each filtration.

Antigens for hyperimmune serum production. Five strains (nos. 611, 658, 697, 956/2 and Y98) were selected for the production of antiserum. The strains were grown in RB for 2-4 days, centrifuged at $40000 \mathrm{~g}$ for $30 \mathrm{~min}$. at $4^{\circ} \mathrm{C}$ in a MSE 18 angle-head centrifuge, washed three times in BSS and finally resuspended in sterile distilled water to a 200-fold concentration of the original volume. After homogenisation, the suspension was disintegrated ultrasonically with a MSE-Mullard Ultrasonic Disintegrator 60W by the method of Mackay (1969). After estimations for total protein, the concentrations of the mycoplasma suspensions were adjusted to $2 \mathrm{mg}$ of protein per $\mathrm{ml}$. Because of import regulations, it was necessary to incorporate formaldehyde in the diluent of strain Y98 to a final concentration of 1 in 2000. A portion of the mycoplasma suspensions was emulsified in an equal volume of a mixture of Bayol and Falba containing $1 \mathrm{mg}$ per $\mathrm{ml} \mathrm{BCG}$. The remainder was retained as the intravenous (i.v.) vaccine.

Antigens for serological tests. The methods employed were the same as for antigen production for the preparation of hyperimmune sera except that the medium employed was OB, and that the organisms were finally resuspended in phosphate buffered saline (PBS) $p H \mathbf{7} 7 \cdot 2$. After total protein estimations, the suspensions were stored in portions at $-20^{\circ} \mathrm{C}$.

Antigens for polyacrylamide-gel electrophoresis (PAGE). All strains in table I as well as Mycoplasma arginini, strain G230 (no. NCTC 10129) and Acholeplasma laidlawii, strain PG8 (no. NCTC 10116) were grown in $200 \mathrm{ml}$ of OB supplemented with arginine $1 \%$ (w/v) for 
2 days, then centrifuged at $40000 \mathrm{~g}$ for $30 \mathrm{~min}$. The deposits were washed once in BSS and suspended in PBS.

Antiserum production. New Zealand rabbits were vaccinated by the method of Morton, and Roberts (1967), $3 \mathrm{ml}$ of antigen in adjuvant being given by injection into the muscle, dermis and footpad, followed 3 weeks later by $2 \mathrm{ml}$ intramuscularly. The growth-inhibiting titres obtained by this technique alone were unsatisfactory however, and two supplementary i.v. injections of $0.5 \mathrm{ml}$ each were given 1 week apart and 4-5 weeks after the second intramuscular injection. The rabbits were bled 1 week later.

Agar-gel double diffusion (AGDD) test. The method of Ouchterlony (1948) was used. The centre well was $10 \mathrm{~mm}$ in diameter and $10 \mathrm{~mm}$ distant from the peripheral wells, which were $7 \mathrm{~mm}$ in diameter. The antigen suspensions contained $1.0-1.4 \mathrm{mg}$ of protein per $\mathrm{ml}$. The gels were kept in a moist atmosphere at room temperature for 5 days before being photographed.

Indirect haemagglutination $(I H A)$ test. The method used was essentially that of Herbert (1967), the test being performed with fresh sheep RBC. The mycoplasma suspensions were found to agglutinate sheep and guinea-pig RBC, and were therefore absorbed for $1 \mathrm{~h}$ at room temperature with $1 / 4$ of their volume of washed, packed sheep RBC. The optimal preabsorption concentration of antigen was found by chequer-board titrations to be $0.5 \mathrm{mg}$ of protein per $\mathrm{ml}$. The $1 \%$ "serum-saline" used for washing the sensitised and control cells and for finally suspending the RBC contained inactivated serum from a hysterectomyproduced, colostrum-deprived lamb that had never been exposed to mycoplasmal infection; otherwise the diluent and washing medium used throughout was PBS. The tests were performed in U-bottomed microtitration plates (Cookes Engineering Co., Alexandria, Virginia) with a $1.5 \%$ cell suspension, and were read after $18 \mathrm{~h}$ at $4^{\circ} \mathrm{C}$. All sera were inactivated at $56^{\circ} \mathrm{C}$ for $30 \mathrm{~min}$. before titration. The controls comprised known negative sera, the titration of four dilutions ( 1 in 10 to 1 in 80 ) of each test serum against control cells, and the provision of sensitised and control cells with serum-saline only.

Growth-inhibition (GI) test. The method of Dighero, Bradstreet and Andrews (1970) was used. The strains were found to vary in their ability to grow on solid medium; in addition, the titre of the broth culture used to inoculate the plates affected the size of the inhibition zones. Accordingly, OA plates, $85 \mathrm{~mm}$ in diameter were flooded with decimal dilutions of each strain as described above, the antiserum disks being tested in duplicate at each dilution. The results were read up to 10 days later to permit full growth of colonies and expression of antiserum effect, and were taken from that dilution which allowed optimal development of inhibition zones commensurate with ease of reading.

Metabolic-inhibition (MI) test. The method of Taylor-Robinson et al. (1966), was used, the broth being $O B$. Fresh guinea-pig serum was included at a final concentration of $5.7 \%$ $(\mathrm{v} / \mathrm{v})$.

$P A G E$. Phenol-acetic acid-water $(2: 1: 0.5 \mathrm{v} / \mathrm{v} / \mathrm{v})$ extraction of the sedimented organisms and PAGE of the extracted proteins was essentially as described by Forshaw (1972). The gels, which contained $35 \%(\mathrm{v} / \mathrm{v})$ acetic acid, $5 \mathrm{M}$ urea and $7.5 \%(\mathrm{w} / \mathrm{v})$ acrylamide, were stained with $1 \%$ amido black. Background stain was removed electrolytically. The gels were photographed as described by Fiske (1974).

Statistical analysis of results. Antibody-titre ratios between the five strains tested in cross-serological reactions were calculated from the MI and GI tests by the method of Archetti and Horsfall (1950) as applied by Goiš et al. (1974). The rank correlation coefficient of the two tests for each antiserum was calculated by the method of Spearman (1904), the rankings of antibody-titre ratios being scored from 1 (homologous system) to 5 (greatest difference from homologous system).

\section{RESULTS}

\section{Biochemical reactions}

The biochemical reactions of the 10 strains examined are summarised in table II. In general, the reactions of all strains were very similar, differing 
TABLE II

Summary of the biochemical and haemolytic reactions of the 10 ovine mycoplasma strains examined

\begin{tabular}{|c|c|}
\hline Biochemical tests & Reaction* \\
\hline $\begin{array}{l}\text { Glycolysis } \\
\text { Oxidation-fermentation } \\
\text { Phosphatase production } \\
\text { Tetrazolium reduction } \\
\text { (i) aerobic } \\
\text { (ii) anaerobic } \\
\text { Tellurite reduction } \\
\text { aerobic and anaerobic } \\
\text { Methylene-blue reduction ( } 0.003 \%) \\
\text { (i) aerobic } \\
\text { (ii) anaerobic } \\
\text { Methylene-blue inhibition ( } 0.02 \%) \\
\text { Hydrogen-peroxide production } \\
\text { (i) Lind (1970) } \\
\text { (ii) Cole et al. (1968) } \\
\text { Casein digestion } \\
\text { Serum digestion } \\
\text { Gelatin hydrolysis } \\
\text { Aesculin hydrolysis } \\
\text { "Films and spots" production } \\
\text { (i) } 20 \% \text { swine serum } \\
\text { (ii) } 10 \% \text { egg yolk emulsion } \\
\text { plus } 5 \% \text { serum } \\
\text { Haemolysis of erythrocytes } \\
\text { (i) sheep } \\
\text { (ii) guinea-pig } \\
\text { (iii) horse } \\
\text { (iv) human group o }\end{array}$ & $\begin{array}{c}+ \\
\text { Fermentation } \\
- \\
\pm \text { to }+ \\
+ \\
\text { Complete or partial } \\
\text { growth inhibition } \\
\text { (no reduction) } \\
\pm \text { to }+ \\
\pm \text { to }++ \\
\text { Inhibition } \\
\pm \text { to }++ \\
+ \\
- \\
- \\
- \\
-\end{array}$ \\
\hline
\end{tabular}

$*-=$ Negative, $\pm=$ weak, $+=$ moderate, and $++=$ strong reaction; $\alpha=$ green zone around colonies; $\alpha \mathrm{p} \equiv$ clear area, with some unhaemolysed erythrocytes remaining in the zone around colony; $\mathrm{B}=$ clear, cell-free zone around colonies; $\mathrm{r}=$ green ring around indicated zone type.

only in degree. The tests in which the greatest variations were observed were methylene-blue reduction (anaerobic conditions) and hydrogen-peroxide production as determined by the method of Lind (1970).

\section{Sensitivity to antibacterial substances}

The sensitivities of the strains to optochin, digitonin, SPS, and 11 antibiotics are given in table III. All strains were sensitive to digitonin and SPS, although sensitivity to SPS $(5 \%)$ was low, possibly because of the use of undiluted broth cultures as inocula. All strains were also sensitive to kanamycin, chlortetracycline, oxytetracycline, gentamicin and tylosin, and resistant to erythromycin, streptomycin, oleandomycin, polymixin B and nystatin. Two strains only (nos. 956/2 and 650/21) were sensitive to neomycin. 
TABLE III

Sensitivity of ovine mycoplasma strains to optochin, digitonin, SPS, antibiotic and fungicide disks

\begin{tabular}{|c|c|c|c|c|c|c|c|c|c|c|c|c|c|c|c|}
\hline \multirow{2}{*}{$\begin{array}{c}\text { Strain } \\
\text { number }\end{array}$} & \multicolumn{15}{|c|}{ Size of zone of inhibition $(\mathrm{mm})$ of growth of the stated strain produced by } \\
\hline & OP & DIG & $\begin{array}{l}\text { SPS } \\
5 \%\end{array}$ & $\begin{array}{l}\text { SPS } \\
20 \%\end{array}$ & $\mathbf{K}$ & E & $\mathrm{NE}$ & $\mathrm{CT}$ & $\mathbf{S}$ & $\mathrm{OL}$ & NY & OT & GM & PB & TY \\
\hline $\begin{array}{l}956 / 2 \\
650 / 21 \\
Y 98 \\
697 \\
652 \\
658 \\
7 Z 97 \\
8 Z 56 \\
611 \\
672 / 9\end{array}$ & $\begin{array}{r}<1 \\
<1 \\
<1 \\
1 \\
1 \\
<1 \\
<1 \\
<1 \\
<1 \\
<1\end{array}$ & $\begin{array}{l}2 \\
2 \cdot 5 \\
1 \cdot 5 \\
1 \\
2 \cdot 5 \\
3 \\
3 \\
4 \\
1 \cdot 5 \\
2 \cdot 5\end{array}$ & $\begin{array}{l}3 \\
0 \cdot 5 \\
2 \cdot 5 \\
1 \cdot 5 \\
1 \\
1 \cdot 5 \\
2 \cdot 5 \\
2 \\
1 \\
2\end{array}$ & $\begin{array}{l}5 \\
3 \\
6 \\
3 \\
1 \cdot 5 \\
3 \\
4 \\
5 \\
6 \\
3\end{array}$ & $\begin{array}{c}10 \\
8 \\
10 \\
15 \\
5-10 \\
5 \\
10 \\
13 \\
5 \\
10\end{array}$ & $\begin{array}{r}<1 \\
1 \\
0 \\
0 \\
0 \\
0 \\
0 \\
0 \\
0 \\
0 \\
0\end{array}$ & $\begin{array}{r}5 \\
6 \\
0 \\
1 \\
<1 \\
1 \\
0 \\
0 \\
0 \\
1\end{array}$ & $\begin{array}{r}15 \\
9 \\
15 \\
11 \\
13 \\
15 \\
10 \\
15 \\
12 \\
16\end{array}$ & $\begin{array}{l}0 \\
0 \\
0 \\
0 \\
0 \\
0 \\
0 \\
0 \\
1 \\
0\end{array}$ & $\begin{array}{l}0 \\
0 \\
0 \\
0 \\
0 \\
0 \\
0 \\
0 \\
0 \\
0\end{array}$ & $\begin{array}{l}0 \\
0 \\
0 \\
0 \\
0 \\
0 \\
0 \\
0 \\
0 \\
0\end{array}$ & $\begin{array}{r}>20 \\
10 \\
6 \\
10 \\
15 \\
15 \\
15 \\
15 \\
10-15 \\
15\end{array}$ & $\begin{array}{c}13 \\
10 \\
6 \\
5-10 \\
10 \\
8 \\
5 \\
5-10 \\
4 \\
10\end{array}$ & $\begin{array}{l}0 \\
0 \\
0 \\
0 \\
0 \\
0 \\
0 \\
0 \\
0 \\
0\end{array}$ & $\begin{array}{r}13 \\
13 \\
5 \\
15 \\
15 \\
10 \\
15 \\
15 \\
10 \\
10\end{array}$ \\
\hline
\end{tabular}

$\mathrm{OP}=$ Optochin $; \mathrm{DIG}=$ digitonin $; \mathrm{SPS}=$ sodium polyanethol sulphonate; $\mathrm{K}=$ kanamycin $(30 \mu \mathrm{g}) ; \mathrm{E}=$ erythromycin $(5 \mu \mathrm{g}) ; \mathrm{NE}=$ Neomycin $(10 \mu \mathrm{g}) ; \mathrm{CT}=$ chlortetracycline $(25 \mu \mathrm{g}) ;$ $\mathrm{S}=$ streptomycin $(10 \mu \mathrm{g}) ; \mathrm{OL}=$ oleandomycin $(5 \mu \mathrm{g}) ; \mathrm{NY}=$ nystatin $(100 \mathrm{units}) ; \mathrm{OT}=\mathrm{Oxyte}$ tracycline $(25 \mu \mathrm{g}) ; \mathrm{GM}=$ gentamicin $(10 \mu \mathrm{g}) ; \mathrm{PB}=$ polymixin $\mathrm{B}(100 \mathrm{units}) ; \mathrm{TY}=\operatorname{tylosin}(30 \mu \mathrm{g})$.

TABLE IV

Filtration studies with two ovine mycoplasma strains

\begin{tabular}{|c|c|c|}
\hline \multirow{2}{*}{ Filtration details } & \multicolumn{2}{|c|}{ Titre (c.f.u. per ml) of strains } \\
\hline & 658 & Y98 \\
\hline $\begin{array}{l}\text { Unfiltered } \\
\text { Filter } 0.80 \mu \mathrm{m} \text { a.p.d. } \\
\text { Filter } 0.45 \mu \mathrm{m} \text { a.p.d. } \\
\text { Filter } 0.22 \mu \mathrm{m} \text { a.p.d. }\end{array}$ & $\begin{array}{c}1.0 \times 10^{9} \\
1.1 \times 10^{7} \\
6.6 \times 10^{3} \\
0\end{array}$ & $\begin{array}{c}5.5 \times 10^{8} \\
6.8 \times 10^{6} \\
1.1 \times 10^{3} \\
0\end{array}$ \\
\hline
\end{tabular}

a.p.d. = Average pore diameter.

c.f.u. = Colony-forming units.

The filtrations were performed sequentially on one sample of each test strain.

\section{Filtration studies}

The results for two strains are presented in table IV. The strains resembled Mycoplasma dispar (Gourlay and Leach, 1970) in their poor filtrability through Millipore filters. This might have been due to growth in clumps.

\section{Agar-gel double diffusion tests}

The antigen suspensions of the five selected strains showed three to seven precipitin lines against each of the five prepared antisera. The number of lines 
TABLE V

Titres obtained in cross-titration of five ovine mycoplasma strains by the indirect haemagglutination test

\begin{tabular}{l|rrrrr}
\hline \multirow{2}{*}{$\begin{array}{c}\text { Strain } \\
\text { number }\end{array}$} & \multicolumn{4}{|c}{ Titres for the stated strain of rabbit antisera prepared against strains } \\
\cline { 2 - 6 } & \multicolumn{9}{c}{ Y56/2 } & \multicolumn{3}{c}{ Y98 } & 697 & 658 & 611 \\
\hline $956 / 2$ & $\mathbf{8 1 9 2 0}$ & 163840 & 40960 & 327840 & 81920 \\
Y98 & 20480 & 20480 & 10240 & 5120 & 5120 \\
697 & 40960 & 10240 & 40960 & 20480 & 20480 \\
658 & 5120 & 640 & 2560 & 2560 & 2560 \\
611 & 10240 & 320 & 2560 & 1280 & 2560 \\
\hline
\end{tabular}

Homologous titres are in bold type.

produced by each mycoplasma suspension varied little with different antisera. Fewest lines (three to four) were given by strains 956/2 and Y98. Strain 697 produced four to five lines against each antiserum, no. 658 produced four to six lines and no. 611 produced four to seven lines (see fig. 1).

\section{Indirect haemagglutination tests}

The results of IHA cross-titration tests between the five strains to which antisera were raised are given in table V. No significant differences could be demonstrated between any of the strains. In the same tests four of the strains were titrated against antisera to 24 other mycoplasma species (table VI). These titrations revealed moderate reactivity against four antisera $(M$. gallinarum, $M$. gallisepticum, $M$. neurolyticum and $M$. spumans) and high reactivity to a further four antisera (M. anatis, M. hyorhinis (strains 7 and GDL), M. maculosum and $M$. pulmonis). However, of the strongly reacting antisera only the antiserum to $M$. hyorhinis (strain GDL) showed reactivity by the AGDD test, a single faint precipitin line developing between this antiserum and all five antigen wells.

\section{Metabolic-inhibition and growth-inhibition tests}

Tables VII (MI tests) and VIII (GI tests) show the results of the titration of all 10 ovine mycoplasma strains against the antisera produced against five of the strains. All strains cross-reacted by these tests, confirming that they belonged to the same species. The MI and GI tests, however, showed antigenic differences among the strains tested, and a comparison for relatedness was made by the method of Goiš et al. (1974). The antibody-titre ratios shown in table IX were calculated from the results of the MI and GI serological tests only, as no intraspecific distinctions were made by the IHA tests. Strains $956 / 2$ and Y98 were most closely related to each other and most dissimilar to 611, which like strain 658 was most closely related to strain 697 . The rank correlation coefficient, a measure of the agreement between tests in the ranking of 
TABLE VI

Titres obtained in indirect haemagglutination tests with ovine mycoplasma strains against reference antisera to other mycoplasmas

\begin{tabular}{|c|c|c|c|c|}
\hline \multirow{2}{*}{$\begin{array}{l}\text { Antiserum } \\
\text { against strain }\end{array}$} & \multicolumn{4}{|c|}{$\begin{array}{c}\text { Titres of the stated antiserum as demonstrated by } \\
\text { ovine mycoplasma strain }\end{array}$} \\
\hline & $956 / 2$ & Y98 & 658 & 611 \\
\hline $\begin{array}{l}\text { M. anatis (1340)* } \\
\text { M. arginini (G230) } \\
\text { M. arthritidis (PG6) } \\
\text { M. canis (PG14) } \\
\text { M. capri (PG3) } \\
\text { M. fermentans (PG18) } \\
\text { M. gallinarum (PG16) } \\
\text { M. gallisepticum (PG31) } \\
\text { M. granularum (BTS 39) } \\
\text { M. hyorhinis (7) } \\
\text { M. hyorhinis (GDL) } \\
\text { M. iners (PG30) } \\
\text { M. maculosum (PG15) } \\
\text { M. meleagridis (17529) } \\
\text { M. mycoides (PG) } \\
\text { M. neurolyticum (Type A) } \\
\text { M. orale 1 (CH-19299) } \\
\text { M. orale } 2 \text { (CH-20247) } \\
\text { M. orale } 3 \text { (DC-333) } \\
\text { M. pneumoniae (FH-Liu) } \\
\text { M. pulmonis (Ash) } \\
\text { M. salivarium (PG20) } \\
\text { M. spumans (PG13) } \\
\text { Acholeplasma laidlawii (PG8) }\end{array}$ & $\begin{array}{c}640-1280 \\
\text { ND } \\
\text { ND } \\
40 \\
10 \\
10 \\
160-320 \\
80 \\
10 \\
320-640 \\
>1280 \\
80 \\
640 \\
40 \\
<10 \\
\text { ND } \\
\text { ND } \\
40 \\
40 \\
10 \\
1280 \\
<10 \\
320 \\
40\end{array}$ & $\begin{array}{c}80 \\
10 \\
10 \\
20 \\
<10 \\
<10 \\
80 \\
160-320 \\
<10 \\
160-320 \\
1280 \\
40 \\
>1280 \\
10 \\
<10 \\
80 \\
20 \\
\text { ND } \\
<10 \\
10 \\
640-1280 \\
<10 \\
\text { ND } \\
40\end{array}$ & $\begin{array}{c}320-640 \\
20 \\
20 \\
40-80 \\
<10 \\
10 \\
80 \\
160 \\
10 \\
320 \\
640-1280 \\
40 \\
>1280 \\
20 \\
<10 \\
320 \\
20 \\
40 \\
20 \\
10 \\
320-640 \\
<10 \\
40 \\
80\end{array}$ & $\begin{array}{c}640 \\
10-20 \\
20 \\
40 \\
<10 \\
<10 \\
80 \\
80-160 \\
<10 \\
320 \\
1280 \\
40 \\
>1280 \\
40 \\
<10 \\
320 \\
40 \\
20-40 \\
20 \\
10 \\
1280 \\
<10 \\
40 \\
80\end{array}$ \\
\hline
\end{tabular}

All sera were titrated in duplicate.

$\mathrm{ND}=$ not done.

* = Strain designations are given in parenthesis.

$t=$ Prepared by the authors by the method described in the text.

All other mycoplasma reference antisera were obtained from the National Institutes of Health, Bethesda, USA.

relatedness, was 1.0 for strains $956 / 2$, Y98 and 658 (significant to $5 \%$ level), 0.925 for strain 697 (significant to the $10 \%$ level) and 0.675 for strain 611 (not significant). Consideration of the relation, calculated or apparent, of all 10 strains emphasises the apparent polarisation of SPA and non-SPA strains at opposite ends of the antigenic spectrum, strains $658,7 \mathrm{Z} 97,8 \mathrm{Z} 56$ and 611 appearing at one end and strains 956/2,650/21 and Y98 at the other. However, strains 652 and 672/9 did not fit this observation, although the animal from which strain $672 / 9$ was isolated belonged to a flock in which SPA occurred.

Strains 658 and $Y 98$ were also tested by the MI test against 40 hyperimmune sera, including the 24 antisera listed in table VI, and the following 15 antisera obtained from the FAO/WHO International Reference Centre for Animal Mycoplasmas, Aarhus, Denmark: $M$. agalactiae subsp. agalactiae (PG2), $M$. agalactiae subsp. bovis (Donetta), M. bovigenitalium (PG11), M. bovirhinis (PG43), M. bovoculi (M165/69), M. capricolum (Calif. Kid), M. dispar (462/2), 
TABLE VII

Comparison of 10 ovine mycoplasma strains by the metabolic-inhibition test

\begin{tabular}{l|rrrrr}
\hline \multirow{2}{*}{$\begin{array}{l}\text { Strain } \\
\text { number }\end{array}$} & \multicolumn{5}{c}{ Titres of inhibition of the indicated strain by antisera prepared } \\
& \multicolumn{5}{|c}{ against strain } \\
\cline { 2 - 6 } & $956 / 2$ & Y98 & 697 & 658 & 611 \\
\hline & & & & & \\
$956 / 2$ & 5120 & 320 & 320 & 80 & 40 \\
$650 / 21$ & 320 & $<10$ & 40 & 10 & 10 \\
Y98 & 640 & 640 & 640 & 640 & 160 \\
697 & 320 & 20 & 2560 & 160 & 320 \\
652 & 160 & 20 & 320 & 40 & 20 \\
658 & 160 & 10 & 320 & 2560 & 160 \\
$7 Z 97$ & 80 & 40 & 2560 & 5120 & 160 \\
$8 Z 56$ & 80 & 40 & 640 & 1280 & 40 \\
611 & 20 & 10 & 40 & 40 & 1280 \\
$672 / 9$ & 80 & 10 & 40 & 40 & 160 \\
\hline
\end{tabular}

Homologous titres are in bold type.

TABLE VIII

Comparison of 10 ovine mycoplasma strains by the growth-inhibition test

\begin{tabular}{|c|c|c|c|c|c|}
\hline \multirow{2}{*}{$\begin{array}{l}\text { Strain } \\
\text { number }\end{array}$} & \multicolumn{5}{|c|}{$\begin{array}{c}\text { Size }(\mathrm{mm}) \text { of the zone of inhibition* of the stated strain produced } \\
\text { by rabbit antiserum to strain }\end{array}$} \\
\hline & $956 / 2$ & Y98 & 697 & 658 & 611 \\
\hline $\begin{array}{l}956 / 2 \\
650 / 21 \\
Y 98 \\
697 \\
652 \\
658 \\
7 Z 97 \\
8 Z 56 \\
611 \\
672 / 9\end{array}$ & $\begin{array}{l}11 \cdot 0-11 \cdot 5 \\
4 \cdot 0-5 \cdot 5 \\
9 \cdot 5 \\
2 \cdot 5-4 \cdot 0 \\
6 \cdot 0 \\
3 \cdot 0 \\
3 \cdot 5-4 \cdot 0 \\
4 \cdot 0-5 \cdot 0 \\
3 \cdot 0 \\
5 \cdot 5\end{array}$ & $\begin{array}{l}2 \cdot 5 \\
1 \cdot 0-2 \cdot 0 \\
7 \cdot 5-9.5 \\
1 \cdot 0 \\
1 \cdot 5-2 \cdot 0 \\
1 \cdot 5-2 \cdot 0 \\
0 \cdot 5 \\
2 \cdot 5-3 \cdot 0 \\
1.0 \\
2 \cdot 0\end{array}$ & $\begin{array}{l}3 \cdot 5 \\
4 \cdot 5 \\
7 \cdot 5-10 \cdot 0 \\
5 \cdot 5 \\
9 \cdot 0-10 \cdot 0 \\
4 \cdot 5-5 \cdot 0 \\
5 \cdot 0-6 \cdot 0 \\
6 \cdot 5-7 \cdot 0 \\
3 \cdot 0 \\
3 \cdot 5-4 \cdot 0\end{array}$ & $\begin{array}{c}3.5-4 \cdot 5 \\
2 \cdot 5-3 \cdot 0 \\
8 \cdot 0-10 \cdot 5 \\
3 \cdot 5-4 \cdot 0 \\
3 \cdot 0-3 \cdot 5 \\
10 \cdot 5-11 \cdot 5 \\
13 \cdot 0-14 \cdot 0 \\
140 \\
3 \cdot 4-4 \cdot 0 \\
4 \cdot 0\end{array}$ & $\begin{array}{l}3 \cdot 0-3 \cdot 5 \\
1 \cdot 0-1 \cdot 5 \\
2 \cdot 0-3 \cdot 5 \\
3 \cdot 5 \\
3 \cdot 5 \\
1 \cdot 5 \\
3 \cdot 0 \\
2 \cdot 0-3 \cdot 0 \\
8 \cdot 0 \\
5 \cdot 0-5 \cdot 5\end{array}$ \\
\hline
\end{tabular}

Homologous reactions are in bold type.

* The results indicate the range of zone widths from duplicate tests of each antiserum, taken from the concentration of inoculum that provided maximal zone development commensurate with ease of reading.

M. gateae (CS), M. putrefaciens (KS-1), bovine serogroups L (B144 P), 7 (PG50), and 8 (PG51), and ovine serogroups 5 (Goat 145), 6 (Goat 189) and 11 (2-D). Antiserum to $M$. verecundum (107), obtained from Drs Gourlay and Howard of IRAD, Compton, nr. Newbury, Berks, was also included in the tests. No cross-reactions were noted between strain 658 or strain Y98 and any of the antisera tested. 
TABLE IX

Antigenic relatedness among five ovine mycoplasma strains calculated from the results of metabolic-inhibition and growth-inhibition tests

\begin{tabular}{|c|c|c|c|c|c|c|c|c|c|c|}
\hline \multirow{3}{*}{$\begin{array}{l}\text { Strain } \\
\text { number }\end{array}$} & \multicolumn{10}{|c|}{$\begin{array}{l}\text { Homologous/heterologous ratios obtained in the stated test with antiserum } \\
\text { against strain }\end{array}$} \\
\hline & \multicolumn{2}{|c|}{$956 / 2$} & \multicolumn{2}{|c|}{ Y98 } & \multicolumn{2}{|c|}{697} & \multicolumn{2}{|c|}{658} & \multicolumn{2}{|c|}{611} \\
\hline & MI & GI & MI & GI & MI & GI & MI & GI & MI & GI \\
\hline $956 / 2$ & $1 / 1$ & $1 / 1$ & _ & - & - & - & - & - & - & - \\
\hline Y98 & $1 / 4$ & $1 / 2.0$ & $1 / 1$ & $1 / 1$ & - & - & - & - & - & - \\
\hline 697 & $1 / 11.3$ & $1 / 2.3$ & $1 / 11 \cdot 3$ & $1 / 2 \cdot 3$ & $1 / 1$ & $1 / 1$ & - & - & - & - \\
\hline 658 & $1 / 32$ & $1 / 3 \cdot 2$ & $1 / 16$ & $1 / 2.4$ & $1 / 11 \cdot 3$ & $1 / 2 \cdot 0$ & $1 / 1$ & $1 / 1$ & - & - \\
\hline 611 & $1 / 90.5$ & $1 / 3 \cdot 3$ & $1 / 22.6$ & $1 / 4.7$ & $1 / 16$ & $1 / 2.5$ & $1 / 22.6$ & $1 / 3 \cdot 8$ & $1 / 1$ & $1 / 1$ \\
\hline
\end{tabular}

The homologous ratio is defined as $1 / 1$, and the degree of antigenic relatedness is indicated by the closeness of the fractions to unity.

\section{Polyacrylamide-gel electrophoresis}

The protein-banding patterns obtained by PAGE (fig. 2) demonstrated a very close resemblance between all 10 strains. The patterns obtained with $M$. arginini and $A$. laidlawii showed no similarities to those of the 10 strains under examination.

\section{Discussion}

Nine strains of glycolytic mycoplasma isolated from the respiratory tract of sheep in Scotland, and an Australian strain (Y98) of M. ovipneumoniae, were almost completely homogeneous in their reactions in 14 biochemical tests, and their sensitivities to optochin, digitonin, SPS, and 11 antibiotics. Where the same tests were performed, the results agreed with those of Carmichael et al. (1972) and Furlong and Cottew (1973). Furthermore, the appearance of colonies of the Scottish strains and the appearance of organisms from broth cultures stained with MacNeal's stain corresponded with the descriptions given by these authors. Failure to hydrolyse aesculin and sensitivity to SPS and digitonin have been accepted as evidence of belonging to the family Mycoplasmataceae (Williams and Wittler, 1971; Freundt et al., 1973a; Ernø and Stipkovits, 1973) and $M$. ovipneumoniae can therefore be regarded as a member. The resistance shown by all strains to erythromycin is of interest, because only two of 17 species of mycoplasma tested by Ernø and Stipkovits (1973) showed a similar resistance.

The protein-banding patterns obtained with PAGE substantiated the apparent homogeneity of the strains studied. In the IHA test, high levels of sensitivity were obtained with fresh sheep RBC, but no significant differences between strains were revealed, and in fact considerable cross-reactions with antisera to other mycoplasma species occurred. A similar lack of specificity with a high degree of cross-reaction between species was also obtained with 
fresh sensitised cells by Freundt et al. (1973b). Serological intraspecific differences have been shown to be due to membrane antigens: where non-membrane antigens participate in a serological test, as in the complement-fixation test, the ability to make intraspecific distinctions becomes lost (Hollingdale and Lemcke, 1970). Despite the finding that in the IHA test for M. hominis (Hollingdale and Lemcke, 1969) only membrane antigens participate, it is likely that non-membrane antigens are also involved in IHA tests with $M$. ovipneumoniae. This would account not only for the inability to differentiate between strains with this test, but also for the heterologous reactions that occurred with antisera to other species of mycoplasma.

The AGDD tests were also more useful in demonstrating similarities than differences between strains, because there was little difference in the number of precipitin lines produced by each antigen suspension irrespective of the opposing antiserum. For M. pulmonis, Deeb and Kenny (1967) found that heated antigens were required to obtain sub-type specificity with this test, although this finding was not corroborated by Forshaw and Fallon (1972). Pollack, Somerson and Senterfit (1969) showed that $M$. pneumoniae harvested from culture media that had become acid lost its reactivity in immunodiffusion tests. This effect was considered to be due to activation of previously released mycoplasmal enzymes rather than to a direct hydrogen-ion effect. The bulk culture media used to produce AGDD antigens all achieved final $p \mathrm{H}$ levels of 6.2-6.4. It is possible that the poor antigenicity of strains 956/2 and Y98 in these tests compared with that of the other strains examined may have been due to their greater production of, or sensitivity to, such enzymes.

This phenomenon may also be partly responsible, in conjunction with the obligatory treatment of the hyperimmunising antigen with formaldehyde, for the poor performance of $\mathrm{Y} 98$ antiserum in the MI and GI tests.

The MI and GI tests have been found to be extremely specific (Purcell, Chanock and Taylor-Robinson, 1969; Freundt et al., 1973b), and therefore suitable for the demonstration of intraspecific differences (Hollingdale and Lemcke, 1970; Forshaw and Fallon, 1972; Haller, Boiarski and Somerson, 1973; Goiš et al., 1974). Both tests revealed considerable antigenic heterogeneity among the 10 strains of $M$. ovipneumoniae, with possible polarisation of the SPA strains towards one end of the spectrum and non-SPA strains towards the other. The practical implications in the application of the GI test have been pointed out by Goiš et al. (1974), namely that, for routine identification of fresh isolates, antisera to several antigenically different strains would be required. Similar implications in the use of the MI test in sero-epidemiological studies have been observed by Hollingdale and Lemcke (1970), namely that full coverage would be achieved only by testing each serum against several strains of the mycoplasma under consideration. For this reason, the highly sensitive but moderately specific IHA test is probably more suitable for such studies.

In the characterisation of the Y98 biotype (Carmichael et al., 1972), serological comparison was made with only 12 other ovine and caprine strains. Furlong and Cottew (1973) compared their Victoria strains with the Queensland 
Y98 biotype and with Mycoplasma dispar. Thus, the serological relation of the organism to other members of the Mycoplasmatales has been insufficiently investigated. The negative results obtained in the MI tests of strains 658 and Y98 against 40 hyperimmune sera to 33 named mycoplasma species or subspecies and 6 serogroups of bovine or ovine origin, though not fully conclusive, indicates that these strains should be considered as a distinct species with the name $M$. ovipneumoniae (WHO/FAO Committee on Comparative Virology, 1974).

\section{SUMMARY}

Nine strains of glycolytic mycoplasmas isolated from the respiratory tract of apparently healthy sheep, pneumonic sheep and sheep with pulmonary adenomatosis (SPA) were compared with a Queensland strain (Y98) of Mycoplasma ovipneumoniae. All strains were very similar in their reactions in 14 biochemical tests and in their sensitivities to optochin, digitonin, sodium polyanethol sulphonate, and 11 antibiotics. Polyacrylamide-gel electrophoresis and serological cross-reactions by the agar-gel double diffusion, metabolicinhibition (MI) and growth-inhibition (GI) tests also showed that all strains could be classified as $M$. ovipneumoniae.

The MI and GI tests, however, showed considerable intraspecific differences among strains, with apparent polarisation of SPA strains and non-SPA strains at opposite ends of the antigenic spectrum.

Two representative strains were tested by the MI test against antisera to 39 mycoplasma species or serogroups, with negative results.

We are grateful to Messrs A. Sutherland, P. McCrossan and J. Redmond for capable technical assistance, and to Messrs J. Wright and B. Easter for the photographs.

\section{REFERENCES}

Aluotto, B. B., Wittler, R. G., Williams, C. O. AND Faber, J. E. 1970. Standardized bacteriologic techniques for the characterization of mycoplasma species. Int. J. syst. Bact., 20, 35.

ARChETti, I. AND Horsfall, F. L. JR 1950. Persistent antigenic variation of influenza A viruses after incomplete neutralization in ovo with heterologous immune serum. $J$. exp. Med., 92, 441.

Carmichael, L. E., St George, T. D., Sullivan, N. D. and Horsfall, N. 1972. Isolation, propagation and characterization studies of an ovine mycoplasma responsible for proliferative interstitial pneumonia. Cornell Vet., 62, 654.

Clarke, J. K., Brown, V. G. AND Alley, M. R. 1974. Isolation and identification of mycoplasmas from the respiratory tract of sheep in New Zealand. N.Z. vet.J., 22, 117.

COLE, B. C., WARD, J. R. AND MARTIN, C. H. 1968. Haemolysin and peroxide activity of mycoplasma species. J. Bact., 95, 2022.

CoTtew, G. S. 1971. Characterisation of mycoplasmas isolated from sheep with pneumonia. Aust. vet. J., 47, 591.

COTTEW, G. S. AND LEACH, R. H. 1969. Mycoplasmas of cattle, sheep and goats. In The Mycoplasmatales and the L-phase of bacteria, edited by L. Hayflick, New York, p. 527.

DeEB, B. J. AND KeNNY, G. E. 1967. Characterization of Mycoplasma pulmonis variants isolated from rabbits. II. Basis for differentiation of antigenic subtypes. J. Bact., 93, 1425 . 
Dighero, M. W., Bradstreet, C. M. P. and Andrews, B. E. 1970 . Dried paper discs for serological identification of human mycoplasmas. J. appl. Bact., 33, 750.

EDWARD, D. G. FF. 1971. Determination of sterol requirement for Mycoplasmatales. $J$. gen. Microbiol., 69, 205.

ERnø, H. AND STIPKovits, L. 1973. Bovine mycoplasmas: cultural and biochemical studies II. Acta vet. scand., 14, 450.

FABRICANT, J. AND FREUNDT, E. A. 1967. Importance of extension and standardization of laboratory tests for the identification and classification of mycoplasma. Ann. N.Y. Acad. Sci., 143, 50.

FISKE, P. J. 1974. Auxiliary cylindrical lenses for recording bands in narrow tubes. Med. biol. Illust., 24, 160.

FoRshAW, K. A. 1972. Electrophoretic patterns of strains of Mycoplasma pulmonis. J. gen. Microbiol., 72, 493.

Forshaw, K. A. AND FAllon, R. J. 1972. Serological heterogeneity of Mycoplasma pulmonis. J. gen. Microbiol., 72, 501.

Freundt, E. A., Andrews, B. E., Erng, H., Kunze, M. ANd Black, F. T. 1973a. The sensitivity of Mycoplasmatales to sodium polyanethol sulphonate and digitonin. Zbl Bakt. ParasitKde, 1 Abt. Orig., 225, 104.

Freundt, E. A., Ernø, H., Black, F. T., Krogsgaard-Jensen, A. and Rosendal, S. $1973 b$. Evaluation of reference reagents for mycoplasmas. Ann. N.Y. Acad. Sci., 225, 161.

Furlong, S. AND CoTtew, G. S. 1973. Identity of mycoplasmas from sheep pneumonia in Queensland and Victoria. Aust. vet. J., 49, 215.

Goiš, M., Kuksa, F., Franz, J. and Taylor-Robinson, D. 1974. The antigenic differentiation of seven strains of Mycoplasma hyorhinis by growth-inhibition, metabolisminhibition, latex-agglutination, and polyacrylamide-gel electrophoresis. J. med. Microbiol., 7, 105.

GoURLAY, R. N. AND LEACH, R. H. 1970. A new mycoplasma species isolated from pneumonic lungs of calves (Mycoplasma dispar sp. nov.). J. med. Microbiol., 3, 111.

Haller, G. J., Boiarski, K. W. AND Somerson, N. L. 1973. Comparative serology of Mycoplasma pulmonis. J. infect Dis., 127 Suppl. S38.

Herbert, W. J. 1967. Passive haemagglutination. In Handbook of experimental immunology, edited by D. M. Weir, Oxford and Edinburgh, p. 720.

Hollingdale, M. R. AND LemCKe, R. M. 1969. The antigens of Mycoplasma hominis. J. Hyg., Camb., 67, 585.

Hollingdale, M. R. and Lemcke, R. M. 1970. Antigenic differences within the species Mycoplasma hominis. J. Hyg., Camb., 68, 469.

KRAUSS, H. AND WANDERA, J. G. 1970. Isolation and properties of mycoplasma from the respiratory tract of sheep with jaagsiekte in Kenya. J. comp. Path. Ther., 80, 389.

KRAYBILL, W. H. AND CRAWFORD, Y. E. 1964. Tetrazolium and methylene blue for isolation and recognition of Mycoplasma pneumoniae. Bact. Proc., p. 70.

Lind, K. 1970. A simple test for peroxide secretion by Mycoplasma. Acta path. microbiol. scand., B78, 256.

MACKAY, J. M. K. 1969. Tissue culture studies of sheep pulmonary adenomatosis (jaagsiekte). II. Transmission of cytopathic effects to normal cultures. J. comp. Path. Ther., 79, 147.

MACKAY, J. M. K., NisBet, D. K. AND FogGIE, A. 1963. Isolation of pleuropneumonialike organisms (genus Mycoplasma) from cases of sheep pulmonary adenomatosis (SPA). Vet. Rec., 75, 550.

MARMION, B. P. 1967. The mycoplasmas. In Recent advances in medical microbiology, edited by A. P. Waterson, London, p. 170.

Morton, H. E. AND RoberTs, R. J. 1967. Production of anti-mycoplasma (PPLO) antibodies in rabbits. Proc. Soc. exp. Biol. Med., 125, 538.

OUCHTERLONY, O. 1948. In vitro method for testing the toxin-producing capacity of diphtheria bacteria. Acta. path. microbiol. scand., 25, 186. 
Pollack, J. D., Somerson, N. L. And Senterfit, L. B. 1969. Effect of $p$ H on the immunogenicity of Mycoplasma pneumoniae. J. Bact., 97, 612.

Purcell, R. H., Chanock, R. M. and Taylor-Robinson, D. 1969. Serology of mycoplasmas in man. In The Mycoplasmatales and the L-phase of bacteria, edited by $\mathrm{L}$. Hayflick, New York, p. 221.

St George, T. D., Sullivan, N. D., Love, J. A. And Horsfall, N. 1971. Experimental transmission of pneumonia in sheep with a mycoplasma isolated from pneumonic sheep lung. Aust. vet. J., 47, 282.

Somerson, N. L., TAylor-Robinson, D. AND Chanock, R. M. 1963. Haemolysin production as an aid in the identification and quantitation of Eaton agent (Mycoplasma pneumoniae). Am.J. Hyg., 77, 122.

Spearman, C. 1904. Quoted by G. W. Snedecor and W. C. Cochran, in Statistical methods, 6th ed., 1967. p. 194.

Taylor-Robinson, D., Purcell, R. H., Wong, D. C. and Chanock, R. M. 1966. A colour test for the measurement of antibody to certain mycoplasma species based upon the inhibition of acid production. J. Hyg., Camb., 64, 91 .

Taylor-Robinson, D., Somerson, N. L., Turner, H. C. and Chanock, R. M. 1963. Serological relationships among human mycoplasmas as shown by complement-fixation and gel-diffusion. J. Bact., 85, 1261.

WhO/FAO Programme on Comparative Virology, 1974. The FAO/WHO programme on comparative mycoplasmology. Vet. Rec., 95, 457.

Williams, C. O. AND Wittler, R. G. 1971. Hydrolysis of aesculin and phosphatase production by members of the order Mycoplasmatales which do not require sterol. Int. J. syst. Bact., 21, 73. 